\title{
Mouse and hamster mutants as models for Waardenburg syndromes in humans
}

\author{
James H Asher Jr, Thomas B Friedman
}

\begin{abstract}
Four different Waardenburg syndromes have been defined based upon observed phenotypes. These syndromes are responsible for approximately $2 \%$ of subjects with profound congenital hearing loss. At present, Waardenburg syndromes have not been mapped to particular human chromosomes. One or more of the mouse mutant alleles, $P h$ (patch), $s$ (piebald), $S_{p}$ (splotch), and $M^{\text {or }}$ (microphthalmiaOak Ridge) and the hamster mutation Wh (anophthalmic white) may be homologous to mutations causing Waardenburg syndromes. In heterozygotes, phenotypic effects of these four mouse mutations and the hamster mutation are similar to the phenotypes produced by different Waardenburg syndrome mutations. The chromosomal locations and syntenic relationships associated with three of the four mouse mutant genes have been used to predict human chromosomal locations for Waardenburg syndromes: (1) on chromosome $2 q$ near FN1 (fibronectin 1), (2) on chromosome $3 p$ near the proto-oncogene RAF1 or 3q near RHO (rhodopsin), and (3) on chromosome $4 p$ near the proto-oncogene KIT. Waardenburg syndromes show extensive intrafamilial phenotypic variability. Results of our studies with the hamster mutation Wh suggest that this variability may be explained in part by modifier genes segregating within families.
\end{abstract}

Classical Waardenburg syndrome in humans (WS1, MIM 19350) is caused by an autosomal dominant mutation with extensive phenotypic variation observed both within and between families. ${ }^{1-5}$ There have been no reported cases of persons homozygous for WS1. In heterozygotes, the WS1 mutation is highly pleiotropic, affecting at least 18 different

Department of Zoology and Graduate Program in Genetics, 203 Natural Science Building, Michigan State University, East Lansing, Michigan 48824, USA.

J H Asher Jr, T B Friedman

Correspondence to Dr Asher.

Received for publication 5 February 1990. Accepted for publication 27 March 1990. characteristics. ${ }^{2}$ Six of these characteristics form the key to diagnosis: (1) dystopia canthorum, (2) a broad nasal root, (3) hypertrichosis of the medial ends of the eyebrows, (4) hypopigmentation of the skin and head hair, (5) total or partial heterochromia iridis, and (6) congenital unilateral or bilateral deafness. ${ }^{6}$ Some of the phenotypic effects caused by WS1 are illustrated by a 23 year old female who has significant hearing loss and her 5 year old daughter who is profoundly deaf (fig la, b).

Premature graying of head hair and beard occurs in approximately $33 \%$ of subjects with WS1, ${ }^{7}$ while optic abnormalities including iridial hypoplasia, hypopigmentation of the fundus, coloboma, and microphthalmia occur in approximately $51 \%$ of the cases reported. ${ }^{1}$ 7-12 WS1 subjects may also exhibit cleft lip, cleft palate, or cleft face with a frequency of up to $10 \%,{ }^{71}{ }^{14}$ while cardiac abnormalities including septal defects are occasionally observed. ${ }^{2}{ }^{13} 15-18$ In families where radiographical studies have been performed, high frequencies of minor skeletal abnormalities are observed. ${ }^{19-21}$

In certain extended families, dystopia canthorum shows a penetrance of $98 \%$ and serves as a reliable indicator of Waardenburg syndrome. ${ }^{1}$ In these families, penetrance of bilateral profound deafness in heterozygotes was initially reported as $17 \%,{ }^{1}$ but with a larger data set this frequency is closer to $25 \% .{ }^{22}$ The frequency of Waardenburg syndrome among students from schools for the deaf in the Netherlands and Canada is $1.43 \%$ and $2.7 \%$, respectively, with an estimate of affected persons in the general population of $1 / 42000$ and a mutation rate of 1/270 $000 .^{13}$ The WS1 mutation is a significant cause of congenital deafness and hearing impairment in humans.

Observing the range of phenotypes initially reported by Waardenburg, ${ }^{1}$ investigators have defined four different subdivisions of Waardenburg syndromes. Arias, ${ }^{624}$ and later Hageman and Delleman, ${ }^{22}$ suggested that patients with Waardenburg syndrome but lacking dystopia canthorum should be classified as Waardenburg syndrome type II (WS2, MIM 19351). This syndrome is caused by an autosomal dominant mutation. The frequency of profound bilateral deafness among heterozygotes for WS2 is approximately $50 \%,{ }^{22}$ twice the frequency observed among WS1 heterozygotes. This subdivision of 


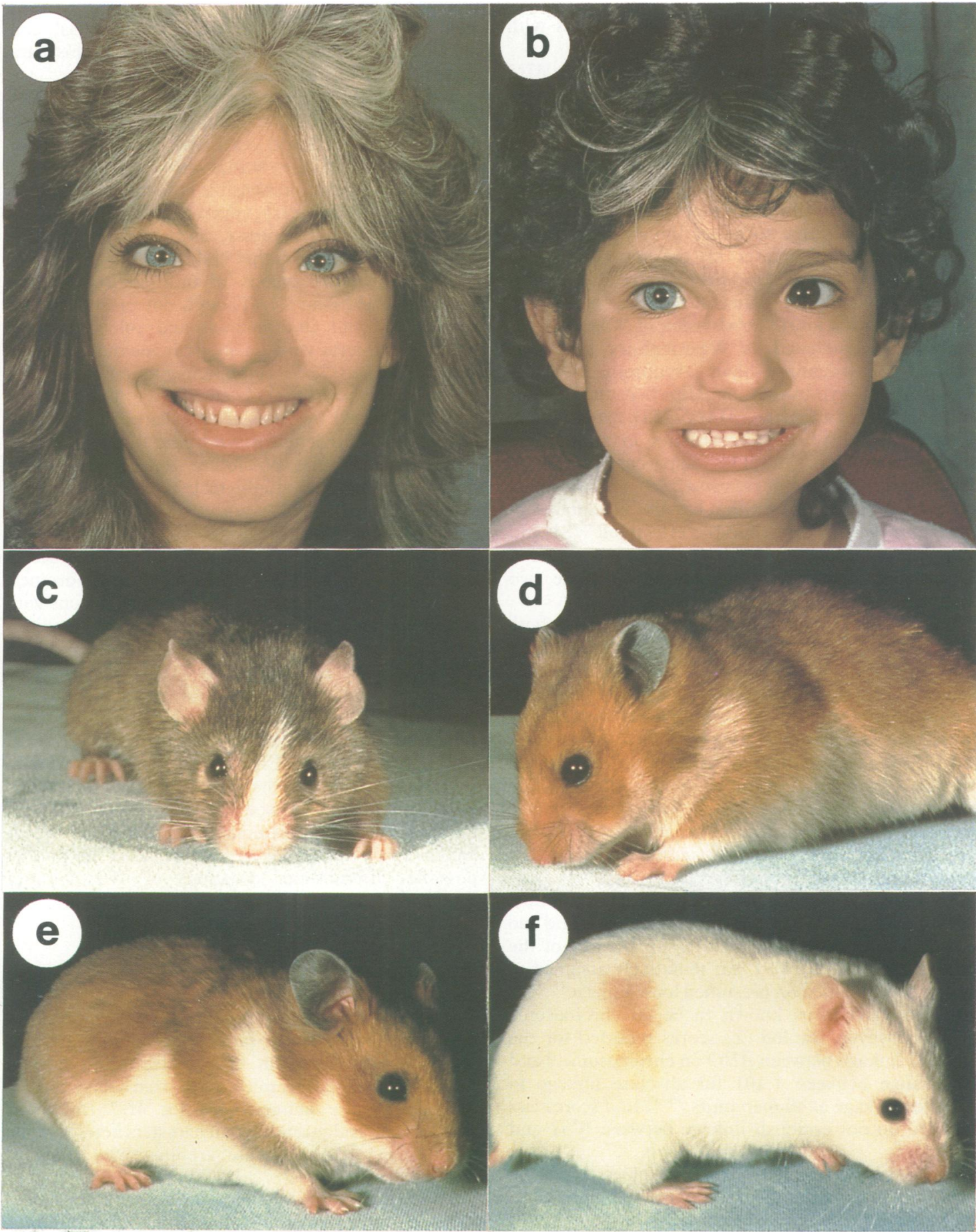

Figure 1 Two human subjects with Waardenburg syndrome (WS1) and mouse and hamster mutants showing similar phenotypes. (a) A 23 year old woman with dystopia canthorum, broad nasal root, white forelock, isochromia iridis, and premature graying. She has a flat auditory brainstem evoked response $(A B R)$ at $100 \mathrm{~dB}$ normal hearing level $(n H L)$ in the right ear and has an $A B R$ threshold of $45 \mathrm{~dB} n \mathrm{~nL}$ in the left ear while normal thresholds are 20 to $25 \mathrm{~dB} n \mathrm{HL}$. When not shaved, her eyebrows are fused. (b) The 5 year old daughter of the subject in $(a)$. The daughter has dystopia canthorum, broad nasal root, fused eyebrows, white forelock, total heterochromia iridis, and profound deafness. She has a 6 month old half sister who gives flat ABR responses in both ears at $130 \mathrm{~dB}$ $n H L$. (c) A C $3 H F / R l M i^{o r} /+$ mouse with a white head blaze, light ears, light eyes and a white belly patch. Homozygotes (Mir/Mir) have a comsletelv white coat and are orofoundlv deaf and eveless. (d) A normal agouti Surian hamster of the genotvne wh/wh:E/e. 
Waardenburg syndrome also contains patients with ocular albinism. 25

Waardenburg syndrome type III (WS3, MIM 14882, Klein-Waardenburg syndrome or Waardenburg syndrome with upper limb abnormalities) is a third subdivision of patients initially considered by Waardenburg ${ }^{1}$ as belonging to WS1. ${ }^{26}$ This mutation also behaves as an autosomal dominant. Heterozygotes with this disorder have the classical WS1 phenotype in addition to upper limb abnormalities, which include hypoplasia of the musculoskeletal system and syndactyly. Some patients also exhibit microcephaly and severe mental retardation. ${ }^{26} 27$

Persons with a fourth subdivision of Waardenburg syndromes, designated as Waardenburg syndrome variant, Waardenburg-Shah syndrome, ShahWaardenburg syndrome, or Hirschsprung disease with pigmentary anomaly (MIM 27758), exhibit many of the classical WS1 characteristics in addition to having megacolon. ${ }^{28-32}$ This apparent variant of Waardenburg syndrome is caused by an autosomal recessive mutation. Megacolon has also been found in association with the phenotypic effects of WS1 and WS2, but Waardenburg-Shah syndrome is considered distinct from the syndromes caused by these two mutations. ${ }^{5}$

The complex phenotypic variation observed both within and between families with Waardenburg syndromes may be explained by one of at least three different genetic models: (1) a single locus with several mutant alleles, (2) a single locus with several mutant alleles each interacting with modifying genes, and (3), as suggested by Waardenburg, ${ }^{1}$ more than one locus each with multiple mutant alleles which interact with modifying genes. Differences in the allelic state of modifying genes are invoked to explain the variation observed both among and within families with Waardenburg syndromes.

At present, there are no confirmed chromosomal assignments for Waardenburg syndromes and no biochemical or molecular data to support any of the above three models. WS1 was tentatively assigned to chromosome 9 based on presumed loose linkage $e^{15} 3334$ with the ABO locus known to be on chromosome 9. ${ }^{34} 35$ However, the lod $(Z)$ scores reported for the assumed linkage between $A B O$ on chromosome 9 and WSI range between $1 \cdot 101$ for absolute linkage to 0.201 for linkage at 40 map units. ${ }^{36-38}$ Lod scores less than 3.0 do not establish linkage between WSI and $A B O .{ }^{39} 40$

Two recent papers may provide clues as to the possible chromosomal location of the mutations causing Waardenburg syndromes. Ishikiriyama et $a l^{41}$ reported a case of sporadic WS1 associated with a paracentric inversion on human chromosome 2 involving breakpoints in bands $2 \mathrm{q} 35$ and $2 \mathrm{q} 37.3$. The child showed typical features of WS1 without the abnormalities usually associated with duplications or deletions involving $2 \mathrm{q}^{42-46}$ So far, a causal connection has not been established between this paracentric inversion and the WS1 phenotype.

In a case involving a deletion of a nearby area, Glass et $a l^{47}$ described a 16 year old proband with craniofacial dysmorphology, extensive scalloped hypopigmentation of the skin, microcephaly, mental retardation, no comprehensible speech, short stature, beaked nose, bilateral corneal ectasia, divergent strabismus, bilateral ptosis, and cleft palate. The hearing capabilities of this child were not reported. The boy was heterozygous for an interstitial deletion involving $2 \mathrm{q} 32.2-\mathrm{q} 33.1$. Though not present in this subject, skeletal abnormalities and coloboma were noted in subjects with deletions involving the same genetic region. ${ }^{48-54}$ Hypopigmentation was not observed in these latter deletions. We note that the subject reported by Glass $e t a l^{47}$ shares many of the features of Waardenburg syndrome type III. These reports suggest the possibility that Waardenburg syndrome mutations might map to human chromosome 2 .

A genetic and developmental analysis of Waardenburg syndromes will determine: (1) the number of genetic loci responsible for Waardenburg syndromes, (2) the number of mutant alleles at a given locus with different phenotypic effects, (3) the primary functions of the loci involved, and (4) the mechanisms by which alterations of these primary functions produce abnormalities of the eye, inner ear, pigmentation, and skeleton. An obvious first step to obtain this information is to assign WS1 and WS2 to particular human chromosomes using RFLP markers with known map positions. To narrow the initial choice of autosomal RFLP markers to be used in such a linkage analysis, mutations in other mammals which may be homologous to WS1 and WS2 can be used to predict possible chromosomal locations of Waardenburg syndromes.

\section{Mouse and hamster mutations}

\section{MOUSE MODELS}

The phenotypic effects produced by WS1 are not unique to man as these same abnormalities are also caused by mutations in dogs, cats, mink, horses, cattle, house mice, deer mice, and Syrian hamsters. ${ }^{55-67}$ A house mouse heterozygous for $\mathbf{M i}^{\text {or }}$ (microphthalmia-Oak Ridge) and Syrian hamsters heterozygous for $W h$ (anophthalmic white) are illustrated in fig lc, $d, e, f$.

The use of chromosomal segments with conserved homologous linkage groups found in several different vertebrate species provides one method of predicting the location of genes in humans causing disease states. Comparing the genetic maps of man and house mouse, there are 241 known homologous autosomal genes found on 68 homologous chromosomal segments 
encompassing all of the autosomes of man and mouse. The average length of a conserved segment in the mouse, homologous to a human chromosomal segment, is $10 \cdot 1 \pm 2 \cdot 2 \mathrm{cM}^{6}{ }^{68}$ Of the 2138 mutant alleles of the house mouse listed by Peters, ${ }^{69} 178$ mutant alleles of 79 loci affect pigmentation. Twentyone of these loci have alleles which produce pleiotropic effects including abnormalities of the skeleton, eye, inner ear, neural or neuromuscular system, internal viscera, reproductive system, haematopoietic system, and endocrine system. Nine of these 79 loci have mutant alleles which affect the development of the inner ear: $d r$ (dreher), $m i$ (microphthalmia), $m u$ (muted), $p a$ (pallid), $P h$ (patch), $s$ (piebald), $S p$ (splotch), $V a$ (varitint-waddler), and $W$ (dominant spotting).

Of these nine loci, $p a, W(K i t), d r, m u$, and $V a$ were eliminated as possible models for Waardenburg syndromes. The primary effect of $p a$ appears to be upon the transport of $\mathrm{Mn}^{++}$which alters the development of melanoblasts and otoliths. ${ }^{70} 71 \mathrm{~W}$ (Kit) appears to alter the mobility and proliferation of neural crest cells, haematopoietic precursors, and primordial germ cells. ${ }^{72-74}$ The $W$ locus has recently been shown to be equivalent to $K i$ t, a proto-oncogene encoding a cell surface protein kinase receptor. ${ }^{75}$ The earliest observed defect caused by $d r$ appears to involve hindbrain development leading to deafness and abnormal behaviour including circling and head tossing, ${ }^{76}$ while $m u$ alters melanoblast development and causes a balance defect similar to the $p a$ mutation. ${ }^{77} \mathrm{Va}$ causes severe abnormalities of vestibular development in addition to its effects on the development of the cochlea and pigmentation which leads to circling behaviour, head tossing, and deafness. ${ }^{78}$ Thus, $p a, W(K i t), d r, m u$, and $V a$ are probably not good models for Waardenburg syndromes.

We suggest that $m i, P h, s$, and $S p$ are possible models for Waardenburg syndromes because of the similarities among their pleiotropic phenotypes and Waardenburg syndromes. If one or more of the mouse genes $P h, s, S p$, and $M i^{\text {or }}$ are homologous to genes causing Waardenburg syndromes, the syntenic relationships between genes in man and mouse can be used to predict the chromosome locations of Waardenburg syndromes. ${ }^{68}{ }^{79-81}$ Of these four loci, alleles of the $m i$ locus (table) exhibit the widest range of phenotypic effects paralleling the variability observed both between and among families with Waardenburg syndromes. Before presenting a discussion of the $m i$ locus, three loci which show some of the phenotypic variation of Waardenburg syndromes are described.

\section{The Ph mouse model}

The $P h$ locus of the house mouse is located on chromosome 5, approximately 37 map units from the centromere. $^{80} 81$ Mapping at the same genetic position are $W$ (dominant spotting) and $R w$ (rumpwhite). ${ }^{82} 83 \mathrm{Ph}, W(K i t)$, and $R w$ each affect pigmentation phenotypes and map $1 \mathrm{cM}$ from the hypervariable region $M s 15-6$ (minisatellite $15-6$ ). ${ }^{84}$ The two alleles at the $P h$ locus cause patches of hypopigmentation and inner ear defects. $P h /+$ mice have skulls which are wider and shorter than normal and

Mutant alleles at the mi locus in the house mouse.

Phenotypic effects

\begin{tabular}{|c|c|c|c|c|}
\hline \multirow[b]{2}{*}{ Allele } & \multirow[b]{2}{*}{ Name } & & \multirow[b]{2}{*}{ References } \\
\hline & & Heterozygotes & Homozygotes & \\
\hline$m i$ & Microphthalmia & $\begin{array}{l}\text { Pale ear pigmentation, white } \\
\text { belly and head patches, } \\
\text { premature gray, light eye } \\
\text { pigmentation }\end{array}$ & $\begin{array}{l}\text { White coat, absence of eye pigmentation, } \\
\text { very small or no eyes, skeletal defects, } \\
\text { abnormal cochlea, dies near weaning }\end{array}$ & 91 \\
\hline$m i^{\text {bw }}$ & Black eyed white & Normal genotype & $\begin{array}{l}\text { White coat, black eyes, skin without } \\
\text { melanocytes }\end{array}$ & 96 \\
\hline$m i^{\mathrm{di}}$ & $\begin{array}{l}\text { Microphthalmia- } \\
\text { defective iris }\end{array}$ & Bright red eye reflex & $\begin{array}{l}\text { White coat, skeletal abnormalities, } \\
\text { abnormal retinal lamination, small eyes, } \\
\text { abnormal iridial shape and pigmentation }\end{array}$ & 97 \\
\hline$m i^{\mathrm{ew}}$ & Eyeless white & $?$ & White coat, very small or no eyes & 69 \\
\hline$m i^{i w}$ & Red eyed white & Normal phenotype & $\begin{array}{l}\text { White coat with some pigmentation } \\
\text { around neck, small red eves }\end{array}$ & 98 \\
\hline$m i^{\mathbf{s p}}$ & Mi spotted & $\begin{array}{l}\text { Normal visible phenotype, } \\
\text { lowered tyrosinase activity, } \\
\text { interacts with other mi alleles }\end{array}$ & $\begin{array}{l}\text { Normal visible phenotype, } \\
\text { lowered tyrosinase activity }\end{array}$ & 99 \\
\hline$m i^{\text {ws }}$ & White spot & White belly spot & White coat, some with small eyes & 100 \\
\hline$M i^{\mathbf{b}}$ & $\begin{array}{l}\text { Microphthalmia- } \\
\text { brownish }\end{array}$ & $\begin{array}{l}\text { Dilute fur pigmentation, } \\
\text { light ears and tail }\end{array}$ & White coat, reduced eye pigmentation & 101 \\
\hline$M i^{\text {or }}$ & $\begin{array}{l}\text { Microphthalmia- } \\
\text { Oak Ridge }\end{array}$ & $\begin{array}{l}\text { Dilute fur pigmentation, } \\
\text { patches of white on head, } \\
\text { belly, and tail, premature } \\
\text { gray, reduced eye and ear } \\
\text { pigmentation }\end{array}$ & $\begin{array}{l}\text { White coat, very small or no eyes, } \\
\text { incisors may fail to erupt, skeletal } \\
\text { defects, deaf }\end{array}$ & $\begin{array}{l}102 \\
103\end{array}$ \\
\hline$M i^{\mathrm{wh}}$ & $\begin{array}{l}\text { Microphthalmia- } \\
\text { white }\end{array}$ & $\begin{array}{l}\text { Dilute fur pigmentation, white } \\
\text { belly patches, light ears, deaf, } \\
\text { abnormal cochlea and vestibule }\end{array}$ & $\begin{array}{l}\text { White coat, small eyes with slight } \\
\text { pigmentation, cochlear and vestibular } \\
\text { abnormalities with deafness }\end{array}$ & 104 \\
\hline
\end{tabular}


have enlarged interfrontal bones ${ }^{82}$ leading to a facial phenotype similar to that observed among Waardenburg syndromes. Homozygotes for $\mathrm{Ph}$ and $\mathrm{Ph}^{e}$ usually die in utero: however, survivors have cleft faces. ${ }^{85}$ Comparisons of the known syntenic relationships between mouse and man identify extensive regions of homology between mouse chromosome 5 and human chromosome $4 \mathrm{p}$ where KIT is found. ${ }^{86}$ Because of the likely homologies between the mouse mutant $P h$ and human WS1, a possible chromosomal position for the location of the gene(s) for Waardenburg syndromes is on human chromosome $4 \mathrm{p}$ closely linked to the proto-oncogene KIT.

\section{The s mouse model}

The $s$ locus of the house mouse is located on chromosome 14 , approximately 43 map units from the centromere. ${ }^{80} 81$ Mutant alleles at the $s$ locus of the mouse cause the production of patches of hypopigmentation and inner ear defects. Homozygotes may be completely white, suffer from megacolon, ${ }^{87}$ and have structural defects of the iris. ${ }^{88}$ In some respects, mice homozygous for mutants of the $s$ locus are phenotypically similar to humans with dominant piebald trait (MIM 17280); however, they may represent a possible model for recessive Waardenburg-Shah syndrome which produces megacolon. ${ }^{30} 31$ There are no reported homologous syntenic relationships between the genetic region containing $s$ in the mouse and a defined chromosomal region in man. ${ }^{81}$ With the identification of additional mutations closely linked to $s$ on mouse chromosome 14, these newly identified mutations could be used to locate a second possible chromosomal position for the location of Waardenburg syndromes.

\section{The Sp mouse model}

$S p$ is a semidominant mutation which exhibits profound effects upon the development of the neural crest. ${ }^{89}$ Heterozygotes $(S p /+)$ usually exhibit small, irregular, ventral, white belly patches. Homozygotes usually die in utero, are frequently missing all neural crest derivatives, and exhibit cranioschisis, rachischisis, and occasionally microcephaly. ${ }^{89}$ The $S p$ locus of the house mouse is located on chromosome 1,36 map units from the centromere and 3 map units on the telomere side of $f n-1$ (fibronectin 1) ${ }^{80} 81$ Extensive homologies exist between this chromosomal region of the house mouse and human chromosome 2q. Eleven homologous syntenic genetic markers have been identified with fibronectin $1(f n-1)$ located 33 map units from the centromere in mouse and FN1 (the human homologue) located in bands $2 \mathrm{q} 34-\mathrm{q} 36 .^{81} 90$ Because of the similarities between effects caused by $S p$ and the deletion reported by Glass et $a l^{47}$ at 2q32.2-q33.1, which causes severe developmental defects remarkably like the defects caused by WS3, these two genes may be homologous. The sporadic WS1 mutation reported by Ishikiriyama et al ${ }^{41}$ associated with an inversion of genetic material from $2 \mathrm{q} 35-\mathrm{q} 37.3$ indicates that genetic alterations of this general chromosomal region may be capable of producing different Waardenburg syndromes. Thus, a third possible location of Waardenburg syndromes is on chromosome $2 \mathrm{q}$ near FN1.

\section{The $M i^{\text {or }}$ mouse model}

$M^{i o r}$, an allele of the $m i$ locus of the house mouse, has been mapped to chromosome 6, 46 map units from the centromere (fig 2). ${ }^{80} 81$ The first mutant allele of this locus, $m i(m i=$ microphthalmia), was induced by a $1500 \mathrm{rad}$ dose of $x$ ray and is classified as a recessive lethal. ${ }^{91} 92$ Heterozygotes, however, have reduced ocular pigmentation, lightly pigmented ears, and frequent white head and belly patches as adults. Thus, $+/+$ and $+/ m i$ mice are easily distinguished. Homozygotes $(\mathrm{mi} / \mathrm{mi})$ usually die at the time of weaning and suffer from microphthalmia and coloboma, ${ }^{93} 94$ abnormal cochlear development producing deafness, ${ }^{95}$ absence of pigment in all tissues, ${ }^{93}$ and numerous skeletal abnormalities including the failure of incisors to erupt. ${ }^{92}$ Nine additional independently arising mutant alleles at the $m i$ locus have been identified by complementation and linkage tests (table). Since some degree of complementation exists between certain of these nine alleles, Hollander ${ }^{105}$ and West $e t a l^{97}$ proposed that the $m i$ locus may be a large complex locus composed of several closely linked genes which are functionally related.

The range of phenotypes of the 10 mutant alleles of $m i$ in heterozygotes (table) parallels much of the variation in phenotypes observed among heterozygotes for Waardenburg syndromes. The phenotypes of $m i /+$ and $M i^{\text {or }} /+$ mice (fig $1 \mathrm{c}$, table) resemble the phenotypes of persons with classical Waardenburg syndrome (WS1) because of white spotting, premature graying, reduction of eye pigmentation, skeletal defects, and less severe hearing abnormalities. The phenotype of $\mathrm{Mi}^{\mathrm{wh}} /+$ mice (table) resembles the phenotype of persons heterozygous for Waardenburg syndrome type II (WS2) because both lack skeletal effects but have increased penetrance for hearing defects. ${ }^{104}$

Phenotypic similarities between mutations at the $m i$ locus and mutations causing Waardenburg syndromes suggest a fourth possible chromosomal position for the location of Waardenburg syndromes. The $m i$ locus is located on mouse chromosome 6 to which 47 other loci have been mapped. ${ }^{69.80}$ The syntenic relationships among homologous genes found on mouse chromosomes 6 and 9 and three human chromosomes, 3,7 , and 12 , are illustrated in fig $2 \mathrm{~A}$ and $\mathrm{B}$. The 

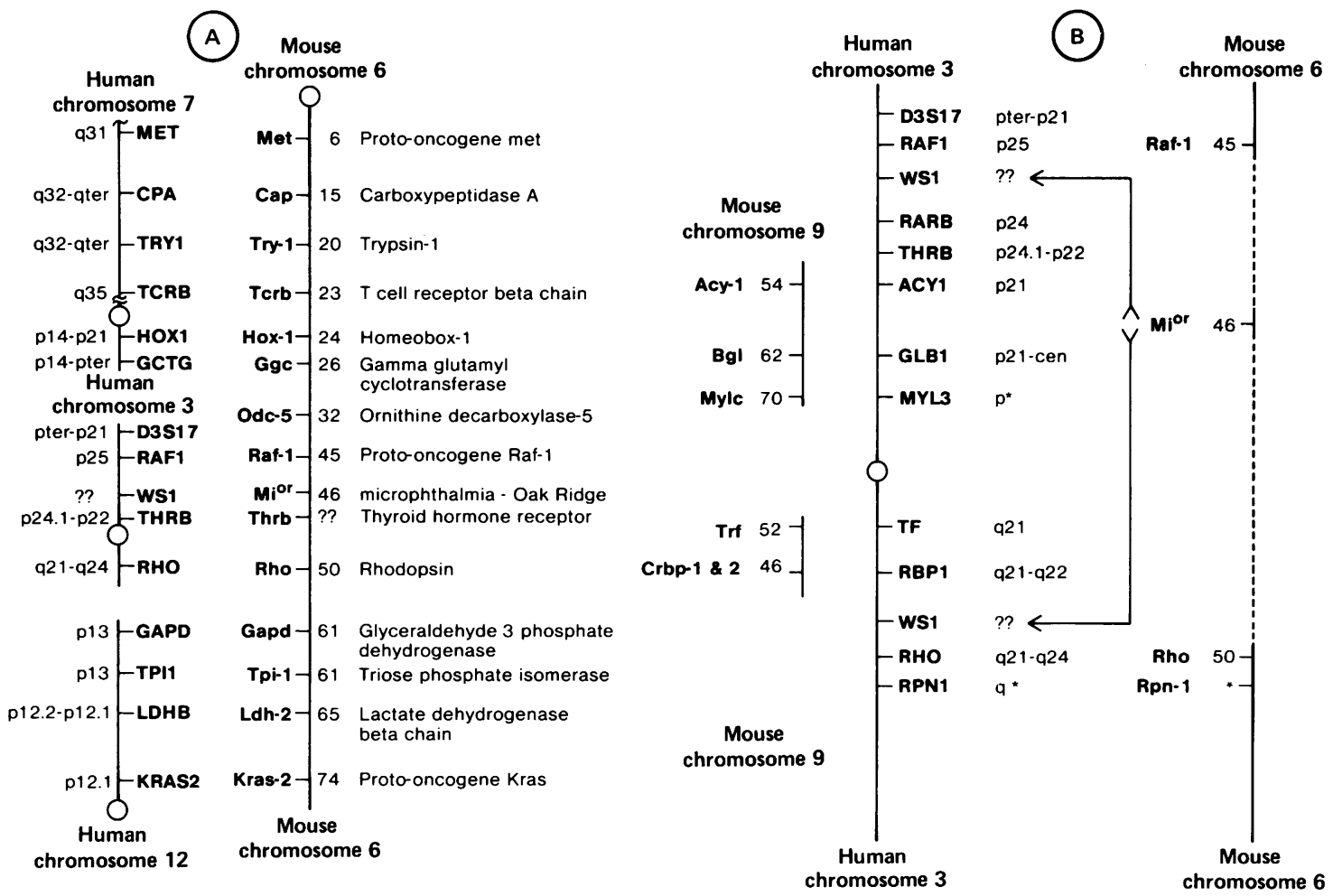

Figure 2 Syntenic relationships between mouse chromosomes 6 and 9 and human chromosomes 3, 7, and 12. (A) Major syntenic relationships between genes on mouse chromosome 6 and human chromosomes 3,7 , and $12 .^{80} 8198$ Note the tight linkage between Mir and Raf-1. The question marks (??) indicate predicted linkage relationships for WS 1 on human chromosome 3 and an Erba-2 related gene on mouse chromosome 6. (B) Some syntenic relationships between genes on human chromosome 3 and mouse chromosomes 6 and 9. In mouse, the distance between Raf -1 and $R$ ho is 5 map units, ${ }^{106}$ while these two markers are on opposite arms of human chromosome 3. For this reason, there are actually two predicted locations for WSI (??): near RAFI on $3 q$ or between RBPI and RHO on 3q. An asterisk (*) next to a chromosome position indicates that the marker is on the chromosome but the exact position has yet to be determined.

closest marker to $m i$ is $R a f-1$ a proto-oncogene, reported to be 1 map unit from $m i$ (fig $2 A) .{ }^{106}$ The human homologue RAF1 has been cloned and mapped to human chromosome $3 .{ }^{107}$ The observations supporting the possibility that WS1 may be on the short arm of human chromosome 3 are: (1) the possible homology between $M i^{\text {or }}$ and WS1, (2) the close linkage between $m i$ and $R a f-1$, (3) the average length of conserved chromosome segments of $10 \cdot 1 \pm 2 \cdot 2 \mathrm{cM}$ of mouse genes whose homologues are found in humans, and (4) the fact that there are at least three established syntenic relationships between mouse chromosome 6 and human chromosome 3 involving RAFl, ${ }^{107} 108$ RHO (rhodopsin), ${ }^{106} 109$ and RPN1 (ribophorin 1). ${ }^{110}$ Given the syntenic relationships between mouse chromosomes 6 and 9 and human chromosome 3 (fig $2 \mathrm{~A}$ and B), another possible location of WS1 is on the long arm of chromosome 3 between the gene for the cellular retinol binding protein (RBP1) found at 3q21-q22 and the gene for rhodopsin (RHO) found at 3q21-q24.
Because of the complex nature of neural crest cell development, there may be several human and mouse loci each with multiple mutant alleles which are capable of producing phenotypic effects similar to Waardenburg syndromes. A study of mutant alleles in mouse and the syntenic relationships between genes in man and mouse suggests that there may be at least four different genetic loci affecting neural crest morphogenesis which could give rise to mutations with pleiotropic effects similar to Waardenburg syndromes. These proposed human genes homologous to specific mouse genes and their proposed locations are: a gene homologous to $S p$ on human chromosome $2 \mathrm{q}$, a gene homologous to $M i^{\text {or }}$ on human chromosome $3 \mathrm{p}$ or $3 \mathrm{q}$, a gene homologous to $\mathrm{Ph}$ on human chromosome $4 \mathrm{p}$, and a gene homologous to $s$ located on mouse chromosome 14 with an unknown syntenic relationship to a human chromosome.

Since the phenotypes of persons with Waardenburg syndromes vary between unrelated kindreds and vary within the same family, it is also possible that there 
are genes at other loci which modify the expression of these major mutations. Epistatic interactions involving modifier genes of pigmentation phenotypes have been identified for some alleles of the four mouse loci discussed above..$^{22111112}$ In the case of mice, epistatic interactions have not been described which involve the modification of hearing phenotypes. Such modifier genes for hearing deficit phenotypes have been identified in one of our laboratories (JA) for the hamster mutation $W h^{113}$ which appears to be homologous to $M i^{\text {or }}$.

\section{HAMSTER MODEL}

The gene $W h$ (anophthalmic white) of the Syrian hamster, discovered independently by one of the authors (JA) in 1962 and by other laboratories, ${ }^{114-116}$ is a highly pleiotropic mutation causing numerous morphological, physiological, and behavioural abnormalities. ${ }^{67} 113$ 117-123 The obvious morphological effects of the $W h$ mutation are to cause homozygotes to be deaf, blind, and white. In addition, $W h$ and $e$ (cream, an unlinked autosomal mutation at the extension locus, $E$ ) show a strong epistatic interaction such that $W h / w h ; E /-$ hamsters are white bellied agouti (Imperial hamster, fig ld and e) while Wh/wh;ele hamsters are black eyed whites (fig lf). The skin and fur colour of the black eyed whites is thought to be one large white patch, a phenotype identical to $m i^{\text {bw }}$ homozygotes in mice. Two other unlinked loci, $s$ (piebald) and $B a$ (banded), interact with $W h$ to produce various sized dorsal white patches. ${ }^{124}$ This variation in the pigmentation phenotype is similar to the range of hypopigmentation anomalies observed among Waardenburg syndromes patients.

While analysing hearing capabilities of hamsters using auditory brain stem evoked response (ABR) analyses, Amedofu ${ }^{113}$ showed that wh/wh;e/e (cream) hamsters have significantly shortened response latencies $(\mathrm{p}<0.05)$ when compared to wh/wh;E/(agouti) hamsters. Thus, $e$ appears to improve hearing sensitivities. Both $W h / w h ; E / e$ (white bellied agouti) and Wh/wh;ele (black eyed white) hamsters have moderate to severe hearing impairment based on both latencies and response thresholds. However, Wh/wh;ele hamsters have lower hearing thresholds than do $W h / w h ; E / e$ hamsters. The interaction between the $e$ locus and the $W h$ locus leads to improved hearing capabilities. Like the $e$ gene in hamsters, there may be a gene in humans which segregates independently of but interacts with Waardenburg syndrome mutations. Thus, one way of explaining the intrafamilial variation observed among subjects with Waardenburg syndromes is the existence of modifying genes segregating within these families.

\section{Discussion}

Based upon the analysis of mouse and hamster mutations, it is possible that as many as four loci may be involved in causing human Waardenburg syndromes. Since the phenotypes associated with the non-allelic mouse $\left(P h, s, S p\right.$, and $\left.M i^{\text {or }}\right)$ and hamster (Wh) mutations overlap extensively, as do the phenotypes of Waardenburg syndromes, linkage analyses performed to locate the chromosome position of Waardenburg syndrome mutations must use very large families defined by a single mutational event. If a given Waardenburg syndrome can be caused by mutations at different loci, analyses of pooled data from different families could result in the failure to localise the mutation to any human chromosome. Based on the mouse mutant phenotypes which are similar to Waardenburg syndromes and the syntenic relationships between mouse and human chromosomes, we propose that a single Waardenburg syndrome mutation might map to one of four possible chromosomal locations: (1) on chromosome 2q near FN1 (fibronectin 1), (2) on chromosome $3 p$ near the proto-oncogene RAF1, (3) on chromosome 3q near RHO (rhodopsin), and (4) on chromosome $4 p$ near the proto-oncogene KIT.

We would like to thank Lori Wallrath, Susan Lootens, and Penny Friedman for their valuable suggestions made during the preparation of this manuscript. We would also like to acknowledge the Deafness Research Foundation, 9 East 38th St, New York, NY 10016 and the Michigan State University All University Research Institutional Grant for their financial support.

\section{Addendum}

Recently we received a preprint from Dr Andrew Read (Foy C, Newton V, Wellesley D, Harris R, Read A. Assignment of the locus for Waardenburg syndrome type 1 to human chromosome $2 \mathrm{q} 37$ and possible homology to the Splotch mouse. Am f Hum Genet, 1990, in press) showing close linkage between WSI and ALPP assigned to $2 \mathrm{q} 37$. Our data from a multilocus linkage analysis of a large WS1 family confirm the observation of Foy et al cited above (Asher et al, submitted). Because of the close linkage between ALPP and FN1 in humans and the corresponding linkage of these genes in mouse, it appears, as we propose herein, that $S p$ (splotch) in mouse is a good model for Waardenburg syndrome type $I$.

1 Waardenburg PJ. A new syndrome combining developmental anomalies of the eyelids, eyebrows and nose root with pigmentary defects of the iris and head hair and with congenital deafness. Am 7 Hum Genet 1951;3:195-253.

2 Wang L, Karmody CS, Pashayan H. Waardenburg's syndrome: variations in expressivity. Otolaryngol Head Neck Surg 1981; 89:666-70.

3 Preus M, Linstrom C, Polomeno RC, Milot J. Waardenburg syndrome-penetrance of major signs. Am $\mathcal{F}$ Med Genet 1983;15:383-8. 
4 Arias S. Letter to the Editor. Diagnosis and penetrance of dystopia canthorum in Waardenburg syndrome type I (WS1). Am f Med Genet 1984;17:863-5.

5 McKusick VA. Mendelian inheritance in man. 8th ed. Baltimore: Johns Hopkins University Press, 1988.

6 Arias S. Genetic heterogeneity in the Waardenburg syndrome. Birth Defects 1971;7:87-101.

7 Pantke OA, Cohen MM. The Waardenburg syndrome. Birth Defects 1971;7:147-52.

8 Calinikos J. Waardenburg's syndrome. $\mathcal{F}$ Laryngol Otol 1963;77: $59-62$.

9 Halbertsma KTA. Een geval van merkwaardige combinatie van aangeboren oogafwijkingen (ptosis, dystopia lateroversa canthi medialis, microcornea plana, microphthalmus, aniridia, microphakia, hypoplasia papillae et retinae, nystagmus intermittens). Ned Tijdschr Geneeskd 1939;83:4985-6.

10 DiGeorge AM, Olmsted RW, Robinson DH. Waardenburg syndrome. If Pediatr 1960;57:649-99.

11 Goldberg MF. Waardenburg syndrome with fundus and other anomalies. Arch Ophthalmol 1966;76:797-810.

12 Delleman JW, Hageman MJ. Ophthalmological findings in 34 patients with Waardenburg syndrome. $\mathcal{F}$ Pediatr Ophthalmol Strabismus 1978;15:341-5.

13 Ray DK. Waardenburg's syndrome. Br $\mathcal{f}$ Ophthalmol 1961;45: 568-9.

14 Meijer R, Walker JC. Waardenburg's syndrome. Plast Reconstr Surg 1964;34:363-7.

15 Aasved H. Waardenburg's syndrome. Acta Ophthalmol (Copenh) 1962;40:622-8.

16 Reed WB, Stone VM, Boder E, Ziprokowski L. Pigmentary disorders in association with congenital deafness. Arch Dermatol 1967;95:176-86.

17 Rugel SJ, Keates EU. Waardenburg's syndrome in six generations of one family. Am $\mathcal{F}$ Dis Child 1965;109:579-83.

18 Smith D, Jones KL. Recognizable patterns of human malformations: genetic, embryology and clinical aspects. 3rd ed. Philadelphia: Saunders, 1982.

19 Divekar MV. Waardenburg's syndrome. F All India Ophthalmol Soc 1957;5:1-5.

20 Stoller FM. A deaf-mute with two congenital syndromes. Arch Otolaryngol 1962;76:42-6.

21 Ahrendts H. Das Waardenburg-syndrome, dargestellt an funf Familien. Z Kinderkeilkd 1965;93:295-313.

22 Hageman MJ, Delleman JW. Heterogeneity in Waardenburg syndrome. Am f Hum Genet 1977;29:468-85.

23 Partington MW. Waardenburg's syndrome and heterochromia iridis in a deaf school population. Can Med Assoc $\mathcal{F}$ 1964;90: $1008-17$.

24 Arias S. Waardenburg syndrome-two distinct types. Am $\mathcal{F}$ Med Genet 1980;6:99-100.

25 Brad LA. Heterogeneity in Waardenburg's syndrome: report of a family with ocular albinism. Arch Ophthalmol 1978;96: 1193-8.

26 Klein D. Historical background and evidence for dominant inheritance of the Klein-Waardenburg syndrome (type III). Am $\mathcal{F}$ Med Genet 1983;14:231-9.

27 Goodman RM, Lewithal I, Solomon A, Klein D. Upper limb involvement in the Klein-Waardenburg syndrome. Am $\mathcal{F}$ Med Genet 1982;11:425-33.

28 Omenn GS, McKusick VA. The association of Waardenburg syndrome and Hirschsprung megacolon. Am $\mathcal{F}$ Med Genet 1979;3:217-33.

29 Kelley RI, Zackai EH. Congenital deafness, Hirschsprung's and Waardenburg's syndrome. Am $\mathcal{F}$ Hum Genet 1981;33:65A.

30 Shah KN, Dalal SJ, Desai MP, Sheth PN, Joshi NC, Ambani LM. White forelock, pigmentary disorder of irides, and long segment Hirschsprung disease: possible variant of Waardenburg syndrome. $\mathcal{F}$ Pediatr 1981;99:432-5.

31 Ambani LM. Waardenburg and Hirschsprung syndromes. $f$ Pediatr 1983;102:802.

32 Meire F, Standaert L, DeLaey JJ, Zeng LH. Waardenburg syndrome, Hirschsprung megacolon, and Marcus Gunn ptosis. Am F Med Genet 1987;27:683-7.

33 Spence MA, Tsui LC. Report of the committee on the genetic constitution of chromosomes 7, 8, and 9. Cytogenet Cell Genet 1987;46:170-87.

34 Cook PJL, Robson ER, Buckton KE, et al. Segregation of ABO, $A K_{1}$, and $A C O N_{s}$ in families with abnormalities of chromosome 9. Ann Hum Genet 1978;41:365-77.

35 Westerveld A, Jongsma APM, Kahn PM, van Someren $\mathrm{H}$, Bootsma D. Assignment of the AK-1:Np:ABO linkage group to chromosome 9. Proc Natl Acad Sci USA 1976;73:895-9.
36 Simpson JL, Falk CT, Morillo-Cucci G, Allen FH Jr, German J. Analysis for possible linkage between the loci for the Waardenburg syndrome and various blood groups and serological traits. Humangenetik 1974;23:45-50.

37 Arias S, Mota M, de Yanez A, Bolivar M. Probable loose linkage between the ABO locus and Waardenburg syndrome type $I$. Hum Genet 1975;27:145-9.

38 Arias S, Mota M. Current status of the ABO-Waardenburg syndrome type I linkage. Cytogenet Cell Genet 1978;22:291-4.

39 Morton NE. Further scoring types in sequential linkage tests, with a critical review of autosomal and partial sex linkage in man. Am f Hum Genet 1957;9:55-75.

40 Watkins PC. Restriction fragment length polymorphisms (RFLP): applications in human chromosome mapping and genetic disease research. BioTechniques 1988;6:310-9.

41 Ishikiriyama S, Tonoki H, Shibuya Y, et al. Waardenburg syndrome type $I$ in a child with de novo inversion (2) (q35-q37.3). Am f Med Genet 1989;33:505-7.

42 Turleau C, Chavin-Colin F, de Grouchy J, Represse G, Beauvais $P$. Familial $t(X ; 2)(p 223 ; q 323)$ with partial trisomy $2 q$ and male and female balanced carriers. Hum Genet 1977;37: 97-104.

43 Dennis NR, Neu RL, Bannerman RM. Duplication 2q33-2q37 due to partial ins $(12 ; 2)$ translocation. Am $\mathcal{F}$ Med Genet 1978;1:271-7.

44 Zankl M, Schwanitz G, Schmid P, et al. Distal 2q duplication: report of two familial cases and an attempt to define a new syndrome. Am $\mathcal{F}$ Med Genet 1979;4:5-16.

45 Warter S, Lausecketer $\mathrm{CH}$, Pennerath A. Etude chromosomique et clinique d'un deletion (2) (q34q36). Hum Genet 1976;32:225-7.

46 Sanchez JM, Pantano AM. A case of deletion 2q35-qter and a peculiar phenotype. F Med Genet 1983;21:147-9.

47 Glass IA, Spindlehurst CA, Aitken DA, McCrea W, Boyd E. Interstitial deletion of the long arm of chromosome 2 with normal levels of isocitrate dehydrogenase. $\mathcal{F}$ Med Genet 1989;26:127-40.

48 Benson $K$, Gordon M, Wassman ER, Chung T. Interstitial deletion of the long arm of chromosome 2 in a malformed infant with karyotype 46XX del(2) (q31q33). Am $\mathcal{F}$ Med Genet 1986;25:405-11.

49 Young RS, Shapiro SD, Hansen KL, Hine LK, Rainosek DR, Guerra FA. Deletion 2q: two new cases with karyotypes 46,XY,del(2)(q3lq33) and 46,XX,del(2)(q36). F Med Genet 1983;20:199-202.

50 Buchanan PD, Rhodes RL, Stevenson CE. Interstitial deletion 2q31-q33. Am $\mathcal{F}$ Med Genet 1983;15:121-6.

51 Al-Awadi SA, Farag TI, Naguib K, et al. Interstitial deletion of the long arm of chromosome 2: $\operatorname{del}(2)(\mathrm{q} 31 \mathrm{q} 33)$. F Med Genet 1983;20:464-5.

52 Franceschini P, Silengo MC, Davi G, Bianco R, Biagoli $M$. Interstitial deletion of the long arm of chromosome 2 (q31q33) in a girl with multiple anomalies and mental retardation. Hum Genet 1983;64:98.

53 Taysi K, Dengler DR, Jones LA, Heersma JR. Interstitial deletion of the long arm of chromosome 2: case report and review of the literature. Ann Genet (Paris) 1981;24:245-7.

54 Pai GS, Rogers JF, Sommer A. Identical multiple congenital anomalies/mental retardation (MCA/MR) syndrome due to $\operatorname{del}(2)(\mathbf{q} 32)$ in two sisters with intrachromosomal insertional translocations in their father. Am $\mathcal{F}$ Med Genet 1983;14: $189-95$.

55 Hudson WR, Durham NC, Ruben RJ. Hereditary deafness in the Dalmatian dog. Arch Otolaryngol 1962;75:39-45.

56 Wolff $D$. Three generations of deaf white cats. $f$ Hered 1942;33:39-43.

57 Wilson TG, Kane F. Congenital deafness in white cats. Acta Otolaryngol (Stockh) 1959;50:269-77.

58 Bosher SK, Hallpike CS. Observations on the histological features, development and pathogenesis of the inner ear degeneration of the deaf white cat. Proc $R$ Soc Lond $B$ 1965;162:147-65.

59 Bosher SK, Hallpike CS. Observations on the histogenesis of the inner ear degeneration of the deaf white cat and its possible relationship to the aetiology of certain unexplained varieties of human congenital deafness. F Laryngol Otol 1966;80:222-35.

60 Brown KS, Bergsma DR, Barrow MV. Animal models of pigment and hearing abnormalities in man. Birth Defects 1971;7:102-9.

61 Shackelford RM, Moore WD. Genetic basis of some white phenotypes in the ranch mink. $\mathcal{F}$ Hered 1954;45:173-6. 
62 Saunders LZ. The histopathology of hereditary congenital deafness in white mink. Pathol Vet 1965;2:256-63.

63 Hilding DA, Sugiura A, Nakai Y. Deaf white mink: electron microscopic study of the inner ear. Ann Otol Rhinol Laryngol 1967;76:647-63.

64 Cohrs P. Studien zur normalen und pathologischen Anatomi und Histologie des inneran Gehororganes vom Pferde. Arch Ohren Nasen u Kehlkopfheilkd 1928;118:1-63.

65 Grobman AB, Charles DR. Mutant white mice: a new dominant autosomal mutant affecting coat color in Mus musculus. $f$ Hered 1947;38:381-4.

66 McIntosh WB. Whiteside, a new mutation in Peromyscus. $f$ Hered 1956;47:28-32.

67 Asher JH Jr. Concerning the primary defect leading to the pleiotropic effects caused by anophthalmic white $(W h)$ in the Syrian hamster, Mesocricetus auratus. F Exp Zool 1981;217: $159-69$.

68 Nadeau JH. Maps of linkage and synteny homologies between mouse and man. Trends Genet 1989;5:82-6.

69 Peters J. Mouse gene list. Mouse News Letter 1989;83:16-64.

70 Cotzias GC, Tang LC, Miller ST, Sladic-Simic D, Hurley LS. A mutation influencing the transportation of manganese, Ldopa and L-tryptophane. Science 1972;176:410-2.

71 Novak EK, Swank RT. Lysosomal dysfunction associated with mutations at mouse pigment genes. Genetics 1979;92:189-204.

72 Mayer TC, Green MC. An experimental analysis of the pigment defect caused by the $W$ and $S l$ loci in mice. Dev Biol 1968;18:62-75.

73 Mintz B, Russell ES. Gene-induced embryological modifications of primordial germ cells in mouse. $\mathcal{F}$ Exp Zool 1957;134: 207-37.

74 Russell ES. Abnormalities of erythropoiesis associated with mutant genes in mice. In: Gordon AL, ed. Regulation of haematopoiesis. Vol 4. New York: Appleton-Century-Crofts, 1970:649-75.

75 Geissler EN, Ryan MA, Housman DE. The dominant-white spotting (W) locus of the mouse encodes the c-kit protooncogene. Cell 1988;55:185-92.

76 Deol MS. The origin of the abnormalities of the inner ear in dreher mice. F Embryol Exp Morphol 1964;12:727-33.

77 Lyon MF, Meredith R. Muted, a new mutation affecting coat colour and otoliths of the mouse and its position in linkage group XIV. Genet Res 1969;14:163-6.

78 Deol MS. The anomalies of the labyrinth of the mutants varitintwaddler, shaker-2 and jerker in the mouse. $\mathcal{F}$ Genet 1954;52: 562-88.

79 O'Brien SJ, Seuanez HN, Womack JE. Mammalian genome organization: an evolutionary view. Annu Rev Genet 1988;22: 323-51.

80 Davisson MT, Roderick TH, Hillyard AL, Doolittle DP. The locus map of the mouse. Mouse News Letter 1989;84:15-23.

81 Lyon MF. Mouse chromosome atlas. Mouse News Letter $1989 ; 84: 24-45$.

82 Gruneberg H, Truslove GM. Two closely linked genes in the mouse. Genet Res 1960;1:69-90.

83 Searle AG, Truslove GM. A gene triplet in the mouse. Genet Res 1970;15:227-35.

84 Jeffreys AJ, Wilson V, Kelly R, Taylor BA, Bulfield B. Mouse DNA 'fingerprints': analysis of chromosomal localization and germ-line stability of hypervariable loci in recombinant inbred strains. Nucleic Acids Res 1987;15:2823-36.

85 Truslove GM. A new allele at the patch locus in the mouse. Genet Res 1977;29:183-6.

86 Yarden Y, Kuang WJ, Yang-Feng T, et al. Human protooncogene c-kit: a new cell surface receptor tyrosine kinase for an unidentified ligand. $E M B O F$ 1987;6:3341-51.

87 Bielschowsky M, Schofield GC. Studies on megacolon in piebald mice. Aust f Exp Biol Med Sci 1962;40:395-404.

88 Dunn LC, Mohr J. An association of hereditary eye defects with white spotting. Proc Natl Acad Sci USA 1952;38:872-5.

89 Auerbach R. Analysis of the developmental effects of a lethal mutation in the house mouse. 7 Exp Zool 1954;127:305-29.

90 Lalley PA, Davisson MT, Graves JAM, et al. Report of the committee on comparative mapping. Cytogenet Cell Genet 1989;51:503-32.

91 Hertwig P. Neue Mutationen und Koppelungsgruppen bei der Hausmause. Z Induk Abstam Verbung 1942;80:220-46.

92 Gruneberg $\mathrm{H}$. Some observations on the microphthalmia gene in the mouse. F Genet 1948;49:1-13.

93 Muller G. Eine entwicklungsgeschichtliche Unversuchung uber das erbliche Kologom mit Mikrophthalmus bei der Hausmaus. $Z$ Mikrosk Anat Forsch 1950;56:520-58.

94 Packer SO. The eye and skeletal effects of two mutant alleles at the microphthalmia locus of Mus musculus. F Exp Zool 1967; 165:21-46.

95 Deol MS. The relationship between abnormalities of pigmentation and of the inner ear. Proc $R$ Soc Lond $B$ 1970;175:201-17.

96 Kreitner P. Linkage studies in a new black-eyed white mutation in the house mouse (not W). F Hered 1957;48:300-4.

97 West JD, Fisher G, Loutit JF, Marshall MJ, Nisbet NW, Perry VH. A new allele of microphthalmia induced in the mouse: microphthalmia-defective iris $\left(m i^{\text {di }}\right)$. Genet Res 1985;46: 309-24.

98 Southard $\mathrm{JL}$. [ $\mathrm{mi}^{\mathrm{Tw}}$ is a new mutation at the $m i$ locus.] Mouse News Letter 1974;51:23-5.

99 Wolfe HG, Coleman DL. Mi-spotted: a mutation in the mouse. Genet Res 1964;5:432-40.

100 Hollander WF. [ $m i^{\text {ws }}$ is allelic to $m i^{\text {wh }}$.] Mouse News Letter 1964;30:29.

$101 \mathrm{Larsen} M M$. [The new mutation $M i^{\mathrm{b}}$ is allelic to $M i^{\mathrm{wh}}$.] Mouse News Letter 1966;34:40-2.

102 Stelzner KF. [Discovery of $\mathrm{Mi}^{\text {or }}$.] Mouse News Letter 1964;31: $40-1$.

103 Stelzner KF. $\left[\mathrm{Mi}^{\text {or }}\right.$ is an allele of $\mathrm{Mi}^{\text {wh }}$.] Mouse News Letter $1966 ; 34: 40-2$.

104 Deol MS. The neural crest and the acoustic ganglion. 7 Embryol Exp Morphol 1967;17:533-41.

105 Hollander WF. Complementary alleles at the mi-locus in the mouse. Genetics 1968;60:189.

106 Elliott R. DNA restriction fragments variants. Mouse News Letter 1989;83:126-48.

107 Bonner T, O'Brien SJ, Nash WG, Rapp UR. The human homologues of the raf (mil) oncogene are located on human chromosomes 3 and 4 . Science $1984 ; 223: 71-4$.

108 Kozak C, Gunnell MA, Rapp UR. A new oncogene, c-raf, is located on mouse chromosome 6. F Virol 1984;49:297-9.

109 Sparkes RS, Mohandas T, Newman SL, et al. Assignment of the Rhodopsin gene to human chromosome 3. Invest Ophthalmol Visual Sci 1986;27:1170-2.

110 Barton DE, Crimaudo C, Hortsch M, Francke U. The genes for ribophorins I and II are on human chromosomes $3 q$ and 20 and mouse chromosomes 6 and 2, respectively. Cytogenet Cell Genet 1987;46:577.

111 Dunn LC, Charles DR. Studies on spotting patterns. I. Analysis of quantitative variations in the pied spotting of the house mouse. Genetics 1937;22:14-42.

112 Wolfe HG, Coleman DL. Pigmentation. In: Green EL, ed. Biology of the laboratory mouse. 2nd ed. New York: The Blakiston Division, McGraw-Hill, 1966:405-25.

113 Amedofu G. Effects of the gene Wh on the hearing of hamsters using auditory brain-stem evoked responses. PhD dissertation, Michigan State University, East Lansing, 1989.

114 Knapp BH, Polivanov S. Anophthalmic albino: a new mutation in the Syrian hamster. Am Naturalist 1958;92:317-8.

115 Beher ME, Beher WT. A partial dominant for suppression of color in the Syrian hamster. Am Naturalist 1959;93:201-3.

116 Robinson R. Anophthalmic white: a mutant with unusual morphology and pigmentation properties in the Syrian hamster. Am Naturalist 1962;96:183-6.

117 Asher JH Jr. A partial biochemical and morphological description of the action of the gene Wh causing anophthalmia in the Syrian hamster, Mesocricetus auratus. MA thesis, California State College at Long Beach, 1968:1-360.

118 Pratt BM. An analysis of the phenotype and gene action of microphthalmic white $\left(M_{i}{ }^{\text {wh }}\right)$ in the house mouse. $\mathrm{PhD}$ dissertation, Michigan State University, East Lansing, 1979: 1-172.

119 Pratt BM. Site of gene action of the white allele $\left(\mathrm{Mi}^{\text {wn }}\right)$ of the microphthalmic locus: a dermal-epidermal recombination study. F Exp Zool 1982;220:93-101.

120 James SC, Hooper G, Asher JH Jr. Effects of the gene $W h$ on reproduction in the Syrian hamster, Mesocricetus auratus. $\mathcal{F}$ Exp Zool 1980;214:261-75.

121 James SC, Asher JH Jr. A histological examination of the pars distalis from the Syrian hamster mutant anophthalmic white (Wh). F Exp Zool 1981;218:335-50.

122 Asher JH Jr, James SC. The primary ultrastructural defect caused by anophthalmic white $(W h)$ in the Syrian hamster. Proc Natl Acad Sci USA 1982;79:4371-5.

123 Hagen SC, Asher JH Jr. Effects of pinealectomy on reproduction in the Syrian hamster mutant anophthalmic white (Wh). $A m \mathcal{F}$ Anat 1983;167:523-38.

124 Robinson R. Genetic studies on the Syrian hamster. VI. Anophthalmic white. Genetica 1964;35:241-50. 